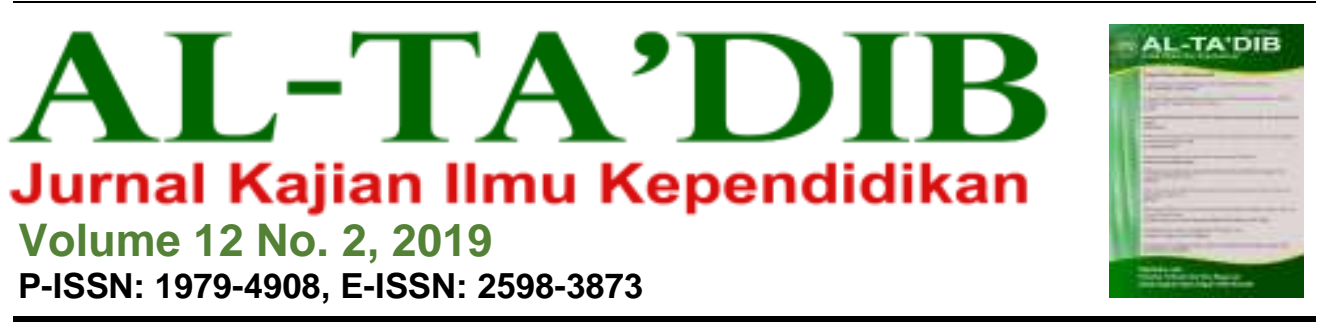

\title{
Analisis Tingkat Karakter Religius Siswa Sekolah Menengah Pertama
}

\author{
Arip Nurrahman ${ }^{1}$, Ardy Irawan ${ }^{2}$ \\ ${ }^{1}$ Universitas Jambi, Indonesia. E-mail: aripnurrahman07@gmail.com \\ ${ }^{2}$ Universitas Jambi, Indonesia.
}

\begin{tabular}{l} 
INFORMASI ARTIKEL \\
\hline Kata Kunci: \\
Pendidikan karakter; \\
religious; sarana sekolah \\
Cara Mensitasi: \\
Nurahman, A.,\& Irawan, \\
A. (2019). Analisis \\
Tingkat Karakter Religius \\
Siswa Sekolah Menengah \\
Pertama. Al-Tadib:Jurnal \\
Kajian Ilmu Kependidikan, \\
12(2), 171-190. \\
DOI: \\
http://dx.doi.org/10.31332/ \\
atdbwv12i2.1575
\end{tabular}

\begin{abstract}
ABSTRAK
Penelitian ini bertujuan untuk menganalisis tingkat karakter religius siswa kelas VIIIA dan VIIIB di SMP Negeri 22 Kota Jambi dalam kehidupan sehari-hari. Teknik pengumpulan data dilakukan dengan cara observasi dan dokumentasi menggunakan instrumen angket karakter. Analisis data dalam penelitian ini menggunakan perhitungan statistik deskriptif. Hasil penelitian menunjukkan bahwa tingkat karakter religius siswa kelas VIIIA SMP Negeri 22 Kota Jambi berada dalam kategori sangat baik, yaitu dengan persentase sebesar $85,7 \%$. Sedangkan tingkat karakter religius siswa kelas VIIIB SMP Negeri 22 Kota Jambi juga berada dalam kategori sangat baik, yaitu dengan persentase sebesar 96,8\%. Secara keseluruhan dapat disimpulkan bahwa siswa kelas VIIIA dan VIIIB SMP Negeri 22 Kota Jambi, memiliki tingkat karakter religius dalam kategori sangat baik yaitu dengan persentase sebesar 91,5\%. Untuk mempertahankan tingkat karakter religius siswa tetap berada dalam kategori sangat baik maka diperlukan pembiasaan di lingkungan sekolah seperti sholat berjamaah di mushola sekolah dan pembacaan Surah Yasin secara rutin..
\end{abstract}




\section{ARTICLE INFO}

Keywords:

Character education, religious, school facility

How to cite:

Nurahman, A.,\& Irawan, A. (2019). Analisis

Tingkat Karakter Religius Siswa Sekolah Menengah Pertama. Al-Tadib:Jurnal Kajian Ilmu Kependidikan, 12(2), 171-190.

DOI:

http://dx.doi.org/10.31332/ atdbwv12i2.1575

\section{Pendahuluan}

Pendidikan sebagai suatu sistem yang berkelanjutan tentunya mempunyai permasalahan yang sangat luas, kompleks dan unik. Baik pada tingkat makro maupun mikro. Selama manusia masih di bumi masih membutuhkan pendidikan, selama itu pula permasalahan pendidikan tidak akan pernah berakhir. Permasalahan pendidikan bukan hanya untuk dilihat dan didengar tetapi juga harus ditemukan pemecahannya melalui penelitian (Situmorang \& Nurrahman, 2017). Pendidikan memegang peranan penting dalam upaya pengembangan sumber daya manusia dan menentukan kemajuan suatu bangsa. Dengan kata lain pendidikan merupakan faktor utama yang berpengaruh dalam menghadapi era globalisasi.

Bangsa Indonesia dan bangsa lain di seluruh dunia sudah masuk ke dalam abad digital dan abad milenium. Ironisnya, dengan semakin bertambah majunya dunia, peringkat Human Development Index (HDI) Indonesia masih tertinggal. Menurut penelitian yang dilakukan oleh United Nations Development Programme (UNDP) yang tertuang dalam laporan Human 
Development Report, pada tahun 2019 HDI Indonesia menduduki peringkat ke-111 dunia. Indonesia masih kalah dengan negara tetangga Singapura di peringkat ke-9, Malaysia di peringkat ke-61, dan Thailand di peringkat ke-77 (Conceicao, 2019). Salah satu indikator yang digunakan dalam menentukan peringkat HDI adalah kualitas pendidikan. Jika dilihat dari posisi Indonesia dalam daftar peringkat HDI, maka perlu perhatian lebih dalam hal perbaikan dan peningkatan kualitas pendidikan di negara ini. Sektor pendidikan di Indonesia perlu berbenah untuk mencapai tujuan pendidikan nasional (Pratikno, 2016).

Pendidikan adalah suatu upaya untuk membantu peserta didik dalam mengembangkan potensi dirinya, baik pada dimensi intelektual moral maupun psikologis. Bagian terpenting dari pendidikan adalah proses bukan hasil akhir karena melalui proses pendidikan maka peserta didik dapat menjadi lebih mengerti dari sebelumnya. Proses tersebut membutuhkan waktu yang lama, bukan satu atau dua hari, tetapi butuh waktu bertahun-tahun untuk mencapainya. Secara tidak sadar peserta didik dalam kesehariannya menjalani pendidikan yang akan mengembangkan kemampuan yang dimiliki. Pendidikan adalah kunci keberhasilan para peserta didik karena dengan pendidikan mereka bisa lebih melek dengan dunia luar dan mampu bersaing dalam bidang apapun. Sebaliknya, tanpa pendidikan maka peserta didik akan semakin buta dengan dunia luar dan tidak akan mampu bersaing dalam bidang apapun (Desstya, Novitasari, Razak, \& Sudrajat, 2017). Pendidikan merupakan pengajaran, yaitu suatu proses nyata untuk mencapai suatu tujuan yang jelas. Tingkat ketercapaian pengajaran dapat dilihat dari prestasi yang dicapai oleh peserta didik. Dengan prestasi yang baik, maka peserta didik dapat diindikasikan telah memiliki pengetahuan yang baik. Dengan indikasi tersebut, dapat pula disimpulkan bahwa tujuan pengajaran atau pendidikan telah tercapai dengan baik (Hamdu \& Agustina, 2011).

Pendidikan tidak hanya didapatkan dari sekolah, namun pendidikan juga bisa diperoleh dari keluarga dan masyarakat sekitar. Oleh karena itu, pendidikan menjadi tanggung jawab bersama antara keluarga, masyarakat, dan pemerintah (Ayuwanti, 2016). Dalam ruang lingkup sekolah, pelaksanaa pendidikan di tingkat sekolah menengah pertama (SMP) masih kurang optimal utamanya pada aspek peserta didik. Siswa di SMP masih kurang peduli dengan adanya pendidikan atau proses pembelajaran. Mereka justru merasa bosan saat proses pembelajaran berlangsung (Jusita, 2016).

Sebagai pengajar atau pendidik, guru merupakan salah satu faktor penentu keberhasilan setiap upaya pendidikan. Oleh sebab itu, seorang guru dituntut untuk dapat mengetahui dan memahami prinsip belajar serta menguasai berbagai keterampilan mengajar agar proses pembelajaran dapat berlangsung dengan baik. Disamping itu, kepercayaan diri peserta didik terhadap hasil belajarnya merupakan salah satu faktor yang mempengaruhi 
hasil belajar siswa dalam proses pembelajaran. Hal ini terkait dengan adanya pandangan peserta didik terhadap pendidik dalam mengajar di kelas. Selain itu, kecerdasan emosional juga salah satu faktor yang ada dalam diri peserta didik yang memengaruhi hasil belajarnya (Indriawati, 2018).

Kenyataanya, praktik pendidikan di Indonesia masih meninggalkan banyak permasalahan. Guru yang semestinya juga perlu menanamkan karakter kepada peserta didik, namun hanya bisa belajar materi di kelas karena dituntut beban akademik. Sebagaimana Darmaningtyas (2005), mengungkapkan bahwa praktik-praktik pendidikan di Indonesia masih dalam kategori "pendidikan rusak-rusakan". Pendidikan formal menampilkan praktik yang bertentangan dengan harapan pendidikan lebih otonom secara politis, terjangkau secara ekonomi, adil secara sosial, toleran, dan pluralis secara budaya. Dengan demikian, persoalan karakter bangsa pada dasarnya adalah hasil dari praktik pendidikan yang tidak berkarakter.

Disinilah letak strategis guru dalam dunia pendidikan. Guru-guru yang ada harus memposisikan diri sebagai guru yang ideal dan inovatif, yakni guru yang mampu menyesuaikan diri dengan tuntutan zaman yang kian maju dan kompetitif, mempunyai kekuatan spiritual, intelektual, emosional, dan sosial yang tinggi, serta kreatif melakukan terobosan dan pembaruan yang kontinyu dan konsisten. Guru yang baik diharapkan mampu menciptakan kesempatan bagi peserta didik untuk memuaskan rasa ingin tahunya, menggunakan seluruh indera dalam melakukan eksplorasi, memperluas pikiran mereka, dan mengembangkan potensi yang dimilikinya mengingat tidak sedikit guru yang kurang memahami potensi yang dimiliki anak didiknya. Hal ini akan berpengaruh pada pola pendekatan dan pembelajaran yang dilakukan (Azhar \& Sa'idah, 2017).

Agar para guru dapat mengintregrasikan tujuan, kegiatan, dan perkembangan anak maka mereka harus memahami kebutuhan dan karakteristik perkembangan anak. Nugraha dan Rahmawati (2007) menyatakan bahwa kriteria utama bagi seorang guru yang ingin sukses menyandang gelar guru profesional adalah membekali diri dengan kemampuan untuk menyelami perkembangan dan karakteristik anak. Selain itu, para guru harus mampu memberi arahan dan bimbingan yang tepat bagi anak agar mereka dapat mengeksplorasi lingkungannya melalui setiap tahap perkembangan yang bermakna dan belajar dalam situasi yang menyenangkan, menarik, serta relevan dengan pengalaman mereka. Guru harus dapat menghubungkan, menyesuaikan, dan mengadaptasi kurikulum sesuai dengan kondisi, kebutuhan, minat, serta kemampuan anak, bukan hanya mengharapkan agar mereka menyesuaikan diri dengan kurikulum yang ada dalam lembaga pendidikan tertentu. Singkatnya, program pembelajaran harus disesuaikan dengan karakteristik dan kebutuhan anak, bukan anak yang harus 
menyesuaikan dengan program pembelajaran guru (Nugraha \& Rahmawati, 2007).

Dalam proses pembelajaran, sikap peserta didik atau karakter peserta didik sangat mempengaruhi hasil belajar peserta didik. Hal ini menunjukkan bahwa karakter sangat berpengaruh besar terhadap peserta didik. Pada abad ke-21, dunia pendidikan mulai beralih dari pendidikan berbasis nilai menjadi pendidikan berbasis karakter. Hal ini dilakukan karena di dalam dunia pendidikan, terdapat banyak peristiwa yang banyak merendahkan harkat dan martabat manusia, dapat dikatakan bahwa pendidikan di Indonesia sedang mengalami krisis karakter. Tingkat moralitas yang rendah, ketidakadilan yang merajalela, dan tingkat solidaritas yang rendah telah mewabah dalam dunia pendidikan (Kardiyem, 2013).

Karakter merupakan pembentuk sikap dan perilaku seseorang dalam bertindak. Karakter mencerminkan bagaimana orang tersebut menjalani kehidupan sehari-hari. Karakter seseorang muncul apabila terjadi interaksi dalam sebuah entitas sosial, baik pada masyarakat perkotaan maupun masyarakat pedesaan (Pratikno, 2016). Karakter mengandung nilai-nilai yang khas (nilai baik, nilai berbudaya, nilai yang berdampak baik dalam lingkungan) dan terpatri dalam diri sehingga akan terwujud dalam perilaku sehari-hari. Karakter secara koheren memancar dari hasil olahpikir (intellectual development), olahhati (spiritual and emotional development), olahraga (physical development), serta olahrasa (affective development) dan karsa (creativity development) seseorang atau suatu kelompok masyarakat (Salahudin \& Alkrienciechie, 2013).

Dalam upaya menanggulangi pengikisan karakter peserta didik, Fauzi, Zainuddin, dan Atok (2017) melakukan penelitian dengan mengedarkan angket untuk mengetahui kedalaman karakter peserta didik, mengerahkan pengajar yang telah berpengalaman, memberikan sumber belajar yang jelas, dan memberikan tindakan pembelajaran seperti strategi pembelajaran, metode pembelajaran, dan model pembelajaran yang tepat bagi para peserta didik. Febrianshari dan Ekowati (2018) menegaskan bahwa penilaian karakter bisa muncul karena sistem pendidikan belum berhasil menciptakan lulusan yang unggul dalam aspek kemampuan kognitif, psikomotorik, dan juga afektif.

Jika pendidikan dihubungkan dengan karakter maka pendidikan karakter diartikan sebagai suatu sistem pendidikan dengan penanaman nilainilai sesuai dengan budaya bangsa dengan komponen aspek pengetahuan (cognitive), sikap perasaan (assection felling), dan tindakan, baik terhadap Tuhan Yang Maha Esa, diri sendiri, masyarakat dan bangsanya (Afandi, 2011). Pendidikan karakter tidak cukup hanya diajarkan melalui mata pelajaran di kelas, tetapi sekolah dapat juga menerapkannya melalui pembiasaan yang diarahkan sebagai upaya pembudayaan pada aktivitas tertentu sehingga menjadi aktivitas yang terpola atau tersistem. Penanaman 
kebiasaan yang baik sangat penting dilakukan sejak awal kehidupan anak. Melalui pembiasaan sejak kecil siswa membiasakan dirinya untuk melakukan sesuatu yang lebih baik. Tidak mudah untuk menumbuhkan kebiasaan baik pada siswa karena memerlukan waktu yang sangat panjang. Namun jika sudah tertanam menjadi kebiasaan maka siswa akan sulit untuk berubah dari kebiasaan tersebut. Agama Islam sangat mementingkan pendidikan kebiasaan karena dengan pembiasaan diharapkan peserta didik mengamalkan ajaran agamanya secara berkelanjutan (Ningsih, 2017).

Menurut Supranoto (2015), Kemendiknas telah merumuskan 18 item karakter yang akan ditanamkan pada setiap peserta didik. Kedelapan belas karakter tersebut antara lain: 1) Religius; 2) Jujur; 3) Disiplin; 4) Kerja Keras; 5) Tanggung Jawab; 6) Toleransi; 7) Kreatif; 8) Mandiri; 9) Demokratis; 10) Rasa Ingin Tahu; 11) Semangat Kebangsaan; 12) Cinta Tanah Air; 13) Menghargai Prestasi; 14) Bersahabat/Komunikatif; 15) Cinta Damai; 16) Gemar Membaca; 17) Peduli Lingkungan; dan, 18) Peduli Sosial. Di antara kedelapan belas item karakter tersebut, terdapat salah satu karakter yang menarik untuk dianalisis, yaitu karakter religius.

Undang-undang No. 20 Tahun 2003 tentang Sisdiknas menyatakan bahwa tujuan pendidikan adalah agar menjadi manusia yang beriman dan bertakwa kepada Tuhan Yang Maha Esa, berakhlak mulia, sehat, berilmu cakap, kreatif, mandiri, dan menjadi warga negara yang demokratis serta bertanggung jawab. Oleh sebab itu, penguatan pendidikan karakter dalam konteks masa kini sangat relevan untuk mengatasi krisis moral yang sedang melanda di Indonesia (Santosa, 2014). Dapat dikatakan bahwa pendidikan karakter merupakan sesuatu yang tidak dapat dipisahkan dari kehidupan manusia. Mengingat pentingnya karakter dalam membangun sumber daya manusia yang kuat, maka pendidikan karakter harus menyertai seluruh aspek kehidupan termasuk dalam lembaga pendidikan. Idealnya pendidikan karakter diintegrasikan ke seluruh aspek kehidupan sekolah (Hidayatullah, 2010).

Menurut Jalaludin dalam Hardiyanti dan Nuryanta (2016), manusia pada hakikatnya mempunyai kecenderungan untuk selalu condong pada agama. Dalam Islam, kecenderungan ini disebut fitrah yang merupakan kelanjutan dari perjanjian antara Tuhan dan ruh manusia sehingga ruh manusia dijiwai oleh sesuatu yang disebut dengan kesadaran yang mutlak dan Maha suci, yang merupakan asal dan tujuan semua yang ada di atas alam semesta ini. Jalaludin lebih lanjut menjelaskan bahwa agama menyangkut kehidupan batin manusia. Oleh karena itu, kesadaran agama dan pengalaman agama seseorang lebih mengambarkan sisi-sisi batin dalam kehidupan yang ada kaitannya dengan sesuatu yang sakral dan dunia gaib. Dari kesadaran agama dan pengalaman agama ini pula kemudian muncul sikap keagamaan yang ditampilkan seseorang. 
Salah satu nilai pendidikan karakter yang dapat distimulasikan dalam diri anak adalah pendidikan karakter religius. Religius menunjuk pada tingkat keterikatan individu terhadap agamanya. Hal ini menunjukan bahwa individu telah menghayati dan menginternalisasikan ajaran agamanya sehingga berpengaruh dalam segala tindakan dan pandangan hidupnya. Pada perkembangannya, religiusitas yang dialami pada remaja dipengaruhi oleh pengalaman keagamaan, struktur kepribadian serta unsur kepribadian lainnya (Ghufron \& Risnawati, 2010).

Menurut Aulia (2016), nilai religius sangat erat kaitannya dengan nilai keagamaan karena nilai religius bersumber dari agama dan mampu merasuk kedalam jiwa seseorang. Nilai religius bersifat mutlak dan abadi, serta bersumber dari kepercayaan manusia. Di dalam Pancasila, karakter nilai religius terletak pada sila pertama yang berbunyi "Ketuhanan Yang Maha Esa". Karakter religius diartikan sebagai suatu sikap dan perilaku yang patuh dalam melaksanakan ajaran agama yang dianutnya, toleran terhadap pelaksana ibadah agama lain, dan hidup rukun dengan pemeluk agama lain. Karakter ini merupakan karakter utama yang harus dinetralisasikan dan dibiasakan kepada anak khususnya peserta didik dalam kehidupannya sehari-hari.

Agama sangatlah penting untuk pedoman hidup manusia karena dengan bekal agama yang cukup akan memberikan dasar yang kuat ketika akan bertindak, dalam nilai religius berisi tentang aturan-aturan kehidupan dan pengendali diri dari perbuatan yang tidak sesuai dengan syariat agama. Nilai religius yang kuat merupakan landasan bagi siswa untuk kelak menjadi orang yang dapat mengendalikan diri terhadap hal-hal yang bersifat negatif (Utami, 2014).

Glock dan Stark dalam Ghufron dan Risnawati (2010) berpendapat bahwa ada lima dimensi religiusitas yang dapat digunakan untuk melihat perilaku religius seseorang, antara lain: a) Dimensi keyakinan (the ideological dimension) yang merupakan dimensi dimana keyakinan yang berhubungan dengan tingkatan sejauh mana seseorang menerima dan mengakui hal-hal yang dogmatik dalam agamanya; b). Dimensi peribadatan atau praktik agama (the ritualistic dimensions) berupa tingkatan sejauh mana seseorang menunaikan kewajiban-kewajiban ritual dalam agamanya; c) Dimensi feeling atau penghayatan (the experiential dimensions) yang merupakan perasaan keagamaan yang pernah dialami dan dirasakan; d) Dimensi pengetahuan agama (the intelectual dimensions) yang menjadi ukuran seberapa jauh seseorang mengetahui dan memahami ajaran agamanya.

Menurut Aulia (2016) nilai-nilai dasar yang menjadi ruhnya pendidikan Islam adalah nilai dasar ubudiyah, moralitas/akhlakul karimah/moralitas, dan nilai nizhamiyah/kedisiplinan. Pertama, nilai dasar ubudiyah meliputi aktivitas manusia sebagai hamba Allah dan selaku khalifah-Nya di muka bumi ini yang hakikatnya adalah dalam rangka berbakti atau mengabdi kepada Allah 
sekaligus mendapatkan ridho-Nya. Firman Allah SWT (QS. Az-Zariyat: 56) yang artinya adalah, "Dan aku tidak menciptakan jin dan manusia melainkan untuk menyembah Aku." Ayat ini menunjukkan bahwa Islam tidak memberikan toleransi setiap upaya, kreasi dan aktivitas manusia yang berakibat menjauhkan seseorang dari rasa syukur, tunduk dan patuh kepada Allah SWT sebagai satu-satunya Dzat yang Maha Agung yang harus disembah dan dipatuhi. Prinsip ini perlu ditransformasikan kedalam dunia pendidikan agar dalam proses pendidikan itu tidak melahirkan output yang sombong dan takabur serta mengkultuskan sains dan teknologi secara sepihak.

Kedua, nilai dasar akhlakul kharimah/moralitas merupakan inti ajaran Islam yang dibawa oleh Rasulullah Saw yang tujuannya membentuk manusia yang berakhlak mulia atau memiliki moralitas yang baik. Rasullulah sendiri bersabda, yang artinya, "Sesungguhnya aku diutus tidak lain dalam rangka menyempurnakan akhlakul kharimah". Islam sangat menjunjung tinggi nilainilai akhlak karena nilai tersebut harus merupakan ruh dari semua perbuatan, aktivitas, kreasi, dan karya manusia. Kualitas perilaku seseorang diukur dari faktor-faktor akhlak sebagai cerminan kebaikan hatinya. Rasullulah Saw dalam sebuah hadits bersabda yang artinya, "Ketahuilah bahwa didalam jasad manusia itu ada segumpal daging, bila baik akan baiklah manusia itu dan apabila rusak, rusak pulalah manusia itu. Ketahuilah itu adalah hati”. Hadits ini menunjukkan bahwa ppapun bentuk pendidikan yang dilaksanakan harus dijiwai oleh nilai-nilai dasar akhlak. Artinya, pendidikan harus mampu melahirkan output yang tidak semata-mata memiliki kemampuan intelektual, ahli dan terampil dalam berbagai bidang, akan tetapi harus juga memiliki budi pekerti luhur atau akhlakul karimah. Figur manusia yang diharapkan adalah menjadi khalifah di muka bumi, yang mampu melahirkan karya terpuji dan yang akan memelihara lingkungannya.

Ketiga, nilai nizhamiyah/kedisiplinan yang diajarkan melalui tugas mulia, bahkan melalui cara-cara peribadatan tertentu. Kedisiplinan menjadi penting dalam Islam karena akan melahirkan kepribadian dan jati diri seseorang dengan sifat-sifat positif. Seseorang yang disiplin akan memiliki etos kerja yang tinggi, rasa tanggung jawab dan komitmen yang kuat terhadap kebenaran, yang akhirnya akan mengantarkannya sebagai sumber daya manusia yang berkualitas.

Utami (2014) dalam penelitannya menemukan bahwa di tingkat sekolah dasar pelaksanaan nilai religius sudah bisa diterapkan namun dengan taraf ruang lingkup sederhana yang mampu diterima oleh siswa. Pelaksanaan nilai religius dalam pendidikan karakter yang dilakukan di sekolah berupa melakukan kegiatan-kegiatan keagamaan yang dilakukan secara rutin yang dijadikan budaya sekolah sehingga siswa akan terbiasa melakukan dan menerapkannya tidak hanya dalam lingkungan sekolah tetapi juga ketika mereka berada di rumah. 
Penelitian yang dilakukan oleh Dedih, Zakiyah, dan Melina (2019) menyimpulkan bahwa dalam kehidupan siswa sehari-hari keluarga adalah fondasi pengembangan karakter (moral) dan intelektual. Dengan demikian, baik atau tidaknya karakter siswa di rumah tergantung pada seberapa baik karakter bagaimana upaya orang tua dalam membimbing dan mengarahkan mereka. Orang tua yang memiliki karakter yang baik dan mampu menerapkan pada anak-anaknya tentu akan membuat anak-anaknya memiliki karakter yang baik. Penelitian Dedih, dkk (2019) ini menemukan bahwa aspek pembinaan nilai-nilai agama dalam keluarga berperan penting karena nampak dalam proses pembiasaan melaksanakan shalat yang ditanamkan orang tua sejak anak berusia dini melalui proses identifikasi. Melalui pembiasann ini orang tua memperlihatkan bagaimana mereka melaksanakan shalat di rumah. Ayah sebagai imam dimakmumi dan diamini oleh istri dan anak-anak merupakan proses pendidikan yang sangat penting. Anak melihat secara langsung bagaimana salat dilakukan dan perilaku apa yang harus dilakukan pada saat salat. Apa yang dilakukan orang tua akan langsung ditiru anak melalui proses identifikasi.

Menurut Sutrisno (2016), rasa dan nilai-nilai religius akan tumbuh dan berkembang seiring dengan pertumbuhan dan perkembangan psikis maupun fisik anak. Perhatian anak terhadap nilai-nilai religi dan pemahaman terhadap agama akan muncul manakala mereka sering melihat dan terlibat dalam acaraacara keagamaan dan rutinitas orang tuanya dalam melaksanakan ibadah. Penanaman nilai-nilai religius sangat erat kaitannya dengan penanaman akhlak kepada anak sejak masa balita, bahkan semasa anak dalam kandungan terutama bagi kedua orang tua. Terkait hal ini, Sutrisno (2016) menjelaskan beberapa strategi yang bisa diterapkan orang tua dalam menanamkan nilai kereligiusan dalam pendidikan kepada anak. Pertama, keteladanan (contoh) dalam pendidikan merupakan bagian dari sejumlah metode yang paling efektif dalam mempersiapkan dan membentuk anak secara moral, spiritual, dan sosial. Kedua, menasehati sebagai salah satu cara yang efektif di dalam usaha membentuk keimanan anak, mempersiapkan moral, psikis dan sosial sebab nasehat sangat berperan dalam menjelaskan kepada anak tentang segala hakikat, menghiasinya dengan moral mulia, dan mengajarinya dengan prinsipprinsip Islam. Ketiga, pengawasan dengan mendampingi anak dalam upaya membentuk akidah dan moral dan mengawasinya dalam mempersiapkannya secara psikis dan sosial serta menanyakan terus tentang keadaannya, baik terkait pendidikan jasmani maupun dalam hal belajarnya. Keempat, penghargaan (reward) yang merupakan pendorong utama dalam proses belajar. Reward dapat berdampak positif bagi anak, yaitu: 1) menimbulkan respon positif; 2) menciptakan kebiasaan yang relatif kokoh dalam dirinya; 3) menimbulkan perasaan senang dalam melakukan suatu pekerjaan yang mendapat imbalan; 4) menimbulkan antusiasme, semangat terus melakukan 
pekerjaan; dan 5) semakin percaya diri. Kelima, hukuman yang merupakan tindakan yang dijatuhkan kepada anak secara sadar dan sengaja, sehingga menimbulkan efek jera. Dengan adanya efek jera itu anak dapat menjadi sadar akan perbuatannya dan berjanji dalam hati untuk tidak akan mengulanginya.

Permasalahan ini juga pernah dikaji dalam penelitian Aulia (2016) yang melihat implementasi nilai religius dalam pendidikan karakter bagi peserta didik di sekolah dasar. Temuan dari penelitian ini adalah melalui agama, peserta didik diajarkan agar selalu berkepribadian baik, berakhlak mulia dan membentuk pribadi yang bermoral. Selain itu, penelitian Kautsar dan Edi (2017) mengungkapkan bahwa dalam rangka menguatkan karakter religius melalui sarana prasarana yaitu pada kegiatan keagamaan di mushola terdapat aktifitas latihan seperti latihan berdakwah, latihan tilawah Quran dan kegiatan Rohis lainnya pada setiap hari Sabtu pukul 15.00-17.35 WIB yang dibimbing oleh guru pembimbing. Kemudian, setiap waktu Ashar sholat berjamaah dan selalu mengadakan perlombaan pada hari-hari besar agama Islam. Namun, dari kedua penelitian tersebut, peneliti belum menemukan adanya tingkat karakter religius siswa di sekolah. Hal ini sangat diperlukan untuk mengukur seberapa jauh pemahaman siswa mengenai pentingnya menerapkan ajaranajaran agama bukan hanya di sekolah tapi juga dalam kehidupan sehari-hari.

Berdasarkan pemaparan masalah diatas, peneliti terdorong untuk melakukan pengkajian terhadap permasalahan tersebut dengan berfokus pada karakter religius siswa SMP Negeri 22 Kota Jambi. Penelitian ini bertujuan untuk menganalisis tingkat karakter religius siswa dalam kehidupan seharihari, dan peneliti juga memaparkan solusi yang relevan dengan character building khususnya karakter religius pada siswa.

Pemilihan SMP Negeri 22 Kota Jambi adalah karena sekolah ini sudah terakreditasi A dan memiliki fasilitas mushola sekolah yang mendukung implementasi karakter religius siswa di sekolah contohnya dengan sholat berjamaah dan kegiatan-kegiatan keagamaan lainnya. Selain itu lokasi sekolah yang berada di Kota Jambi yang masih mempertahankan kebudayaan melayu. Kebudayaan melayu sangat erat kaitannya dengan syiar-syiar agama Islam, dimana nilai-nilai yang diajarkan dalam budaya melayu sangat mirip dengan ajaran-ajaran agama Islam, seperti berpakaian tertutup, budaya musyawarah, dan sopan santun terhadap guru/ustadz.

\section{Metode Penelitian}

Jenis penelitian ini adalah penelitian kuantitatif dengan mengambil data langsung dari responden. Desain penelitian ini menggunakan tipe deskriptif, dimana peneliti mendeskripsikan karakter tingkat religius siswa SMP Negeri 22 Kota Jambi. Penelitian ini dilakukan pada tanggal 22 Oktober 2019 dengan populasi seluruh siswa SMP Negeri 22 Kota Jambi kelas VIII. Responden 
siswa kelas VIIIA sebanyak 28 orang dan siswa kelas VIIIB sebanyak 31 orang. Jumlah total responden pada penelitian ini sebanyak 59 orang.

Teknik pengumpulan data dalam penelitian ini menggunakan angket karakter. Angket terdiri atas 25 pertanyaan tertutup mengenai kesadaran siswa terhadap karakter religius dalam kehidupan sehari-hari. Pemilihan instrumen angket dilakukan dengan teknik adaptasi, yaitu dengan mengadaptasi angket dari penelitian Afifudin (2016), dan menyesuaikannya dengan kebutuhan peneliti, dimana angket yang digunakan sudah teruji validitas dan reliabilitas. Untuk penilaian angket dilakukan dengan menggunakan skala Likert. Menurut Santoso (2006), Skala Likert adalah skala ordinal yang berisi beberapa alternatif jawaban. Dimana penilaian skala Likert meliputi: 1). Sangat Sesuai (SS); 2). Sesuai (S); 3). Kurang Sesuai (KS); dan 4). Tidak sesuai (TS). Dimana skor atau nilai untuk skala tersebut antara lain: 1). Sangat Sesuai $=4 ; 2$ ). Sesuai $=3 ; 3$ ). Kurang Sesuai $=2$; dan 4). Tidak sesuai $=1$. Untuk pengukuran pernyataan (+), diberi nilai 4,3,2,1, dimulai dari skala Sangat Sesuai (SS). Namun, untuk pengukuran pernyataan (-), diberi nilai 4,3,2,1 dimulai dari skala Tidak Sesuai (TS).

\section{Hasil dan Pembahasan}

Karakter religius perlu ditanamkan dalam kehidupan sehari-hari dikarenakan nilai moral generasi penerus bangsa yang terus-menerus menurun. Beberapa bukti penurunan moral saat ini yaitu budaya korupsi, penyalahgunaan dan peredaran narkoba, tawuran antar pelajar dan berbagai kejahatan lainnya. Salah satu faktor penurunan moral tersebut dikarenakan banyaknya siswa yang memiliki rasa kurang peduli terhadap mata pelajaran agama di sekolah. Untuk mengatasi permasalahan itu siswa diharapkan memiliki karakter religius yang baik. Penanaman nilai-nilai religius berkaitan dengan tujuan pendidikan karakter yaitu berupa mental dan sikap peserta didik.

Berdasarkan hasil observasi yang dilakukan pada tanggal 22 Oktober 2019, diperoleh informasi bahwa kegiatan pembelajaran di SMP Negeri 22 Kota Jambi sangat berperan dalam penanaman nilai-nilai karakter. Karakter yang dimaksud diantaranya kedisiplinan dan religius. Pihak sekolah menyediakan waktu istirahat kedua yang lebih lama yaitu pukul 12.20-13.00 WIB atau 40 menit. Hal ini bertujuan agar siswa dapat melaksanakan sholat Zuhur berjamaah di mushola sekolah. Selain itu, di setiap hari Jum'at dilaksanakan kegiatan yasinan rutin yang dilaksanakan juga di mushola sekolah. 
Pengumpulan data dilakukan di dua kelas berbeda, yaitu kelas VIIIA dan VIIIB SMP Negeri 22 Kota Jambi. Sebelum menyebarkan angket karakter, peneliti terlebih dahulu menjelaskan tata cara pengisian dan penilaian angket karakter kepada siswa. Dalam hal ini, peneliti menekankan siswa untuk mengisi dengan jujur sesuai dengan kenyataan mereka dalam kehidupan sehari-hari sebagaimana sikap kejujuran merupakan sikap terpuji yang diajarkan Rasulullah SAW.

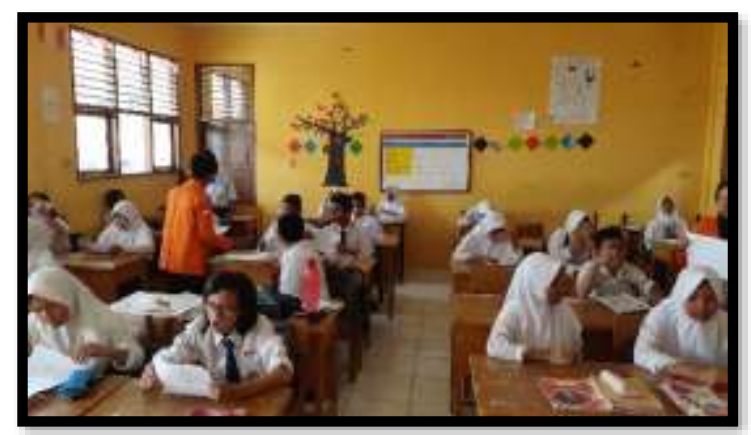

Gambar 1. Pengumpulan data di Kelas VIIIA SMP Negeri 22 Kota Jambi

Angket karakter siswa terdiri atas 25 pertanyaan tertutup mengenai tingkat karakter religius siswa dalam kehidupan sehari-hari. Untuk keperluan analisis data, peneliti menggunakan bantuan software SPSS 25.0, adapun parameter yang dapat dicari menggunakan software ini antara lain mean, median, modus, standar deviasi, rentang, nilai minimum dan nilai maksimum. Parameter-parameter tersebut dapat digunakan untuk menganalisis karakter religius siswa. Peneliti juga mengkategorisasikan karakter religius siswa menggunakan skala Likert. Observasi pertama dilakukan di kelas VIIIA SMP Negeri 22 Kota Jambi dengan jumlah siswa sebanyak 28 orang. Adapun hasil anilisis data, disajikan dalam tabel 1 dan tabel 2 berikut ini.

Tabel 1. Analisis statistik deskriptif perilaku religius siswa kelas VIIIA SMP Negeri 22 Kota Jambi

\begin{tabular}{lc}
\hline Parameter & Hasil \\
\hline Mean & 87,86 \\
Median & 89,00 \\
Modus & 89 \\
Standar Deviasi & 7,168 \\
Rentang & 34 \\
\hline
\end{tabular}




$\begin{array}{ll}\text { Minimum } & 64 \\ \text { Maksimum } & 98\end{array}$

Berdasarkan data pada Tabel 1, diketahui bahwa nilai mean dari 28 siswa kelas VIIIA sebesar 87,86, sedangkan untuk nilai median didapatkan hasil sebesar 89,00. Sementara untuk nilai yang sering muncul/modus didapatkan hasil sebesar 89. Untuk standar deviasi didapatkan hasil sebesar 7,168 , rentang sebesar 34, nilai minimum sebesar 64 dan nilai maksimum sebesar 98 .

Untuk menganalisis karakter religius siswa kelas VIIIA, dapat dilihat dari nilai mean, modus, dan standar deviasi. Berdasarkan data tersebut, didapatkan nilai mean sebesar 87,86 , dimana nilai tersebut berada dalam kategori "Sangat Baik", sedangkan nilai modus sebesar 89, dimana nilai tersebut juga berada dalam kategori "Sangat Baik". Sedangkan standar deviasi digunakan untuk menentukan valid atau tidaknya suatu data, apabila nilai standar deviasi lebih kecil dari nilai mean, maka data tersebut adalah valid. Dari data yang telah diperoleh, diketahui nilai standar deviasi sebesar 7,168, dimana nilainya lebih kecil daripada nilai mean yaitu sebesar 87,86 , maka data dianggap valid.

Tabel 2. Kategorisasi perilaku religius siswa kelas VIIIA SMP Negeri 22 Kota Jambi

\begin{tabular}{lclc}
\hline Interval Skor & Frekuensi & Kategori & Persentase(\%) \\
\hline $25,00-43,75$ & 0 & Sangat Tidak Baik & 0 \\
$43,76-62,50$ & 0 & Tidak Baik & 0 \\
$62,51-81,25$ & 4 & Baik & 14,3 \\
$81,26-100,00$ & 24 & Sangat Baik & 85,7 \\
\hline Jumlah & 28 & & 100 \\
\hline
\end{tabular}

Untuk mengkategorikan karakter religius siswa di kelas VIIIA, perlu ditinjau dari segi penilaian skala Likert. Berdasarkan data pada Tabel 2, terdapat empat siswa yang menjawab angket dalam kategori "Baik" dengan persentase sebesar $14,3 \%$. Sedangkan 24 siswa lainnya menjawab angket dalam kategori "Sangat Baik" dengan persentase 85,7\%. Berdasarkan parameter-parameter yang telah dijelaskan, dapat disimpulkan bahwa tingkat karakter religius siswa kelas VIIIA berada dalam kategori "Sangat Baik". 


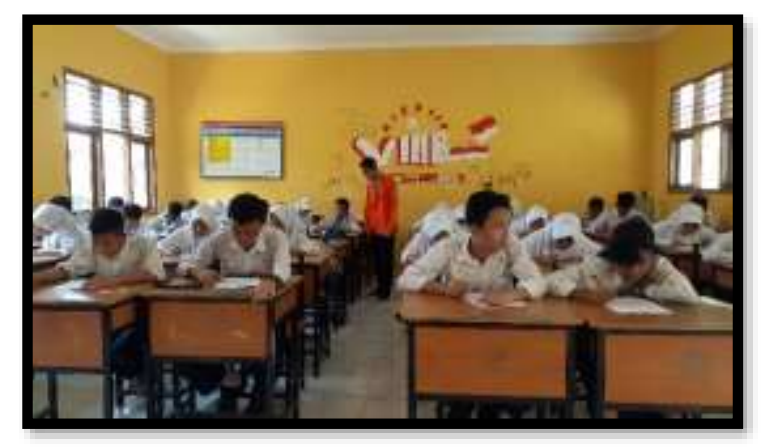

Gambar 2. Pengumpulan data di Kelas VIIIB SMP Negeri 22 Kota Jambi

Observasi kedua dilakukan di kelas VIIIB SMP Negeri 22 Kota Jambi dengan jumlah siswa sebanyak 31 orang. Adapun hasil anilisis data, disajikan dalam Tabel 3 dan Tabel 4 berikut ini.

Tabel 3. Analisis statistik deskriptif perilaku religius siswa kelas VIIIB SMP Negeri 22 Kota Jambi

\begin{tabular}{lc}
\hline Parameter & Hasil \\
\hline Mean & 90,39 \\
Median & 91,00 \\
Modus & 93 \\
Standar Deviasi & 4,287 \\
Rentang & 22 \\
Minimum & 78 \\
Maksimum & 100 \\
\hline
\end{tabular}

Berdasarkan data pada Tabel 3, didapatkan nilai mean dari 31 siswa kelas VIIIB sebesar 90,39. Sedangkan untuk nilai median didapatkan hasil sebesar 91,00. Sementara untuk nilai yang sering muncul/modus didapatkan hasil sebesar 93. Untuk standar deviasi didapatkan hasil sebesar 4,287, rentang sebesar 22, nilai minimum sebesar 78 dan nilai maksimum sebesar 100. Untuk menganalisis karakter religius siswa kelas VIIIB, dapat dilihat dari nilai mean, modus, dan standar deviasi. Berdasarkan data tersebut, didapatkan nilai mean sebesar 90,39, dimana nilai tersebut berada dalam kategori "Sangat Baik", sedangkan nilai modus sebesar 93, dimana nilai tersebut juga berada dalam kategori "Sangat Baik". Sedangkan standar deviasi digunakan untuk menentukan valid atau tidaknya suatu data, apabila nilai standar deviasi lebih kecil dari nilai mean, maka data tersebut adalah valid. Dari data yang telah diperoleh, diketahui nilai standar deviasi sebesar 4,287, dimana nilainya lebih kecil daripada nilai mean yaitu sebesar 90,39, maka data dianggap valid. 
Tabel 4. Kategorisasi perilaku religius siswa kelas VIIIB SMP Negeri 22 Kota Jambi

\begin{tabular}{lclc}
\hline Interval Skor & Frekuensi & \multicolumn{1}{c}{ Kategori } & Persentase(\%) \\
\hline $25,00-43,75$ & 0 & Sangat Tidak Baik & 0 \\
$43,76-62,50$ & 0 & Tidak Baik & 0 \\
$62,51-81,25$ & 1 & Baik & 3,2 \\
$81,26-100,00$ & 30 & Sangat Baik & 96,8 \\
\hline Jumlah & 31 & & 100 \\
\hline
\end{tabular}

Untuk mengkategorikan karakter religius siswa di kelas VIIIB, perlu ditinjau dari segi penilaian skala Likert. Berdasarkan data pada Tabel 4, terdapat satu siswa yang menjawab angket dalam kategori "Baik" dengan persentase sebesar 3,2\%. Sedangkan 30 siswa lainnya menjawab angket dalam kategori "Sangat Baik" dengan persentase 96,8\%. Berdasarkan parameterparameter yang telah dijelaskan, dapat disimpulkan bahwa tingkat karakter religius siswa kelas VIIIB berada dalam kategori "Sangat Baik".

Adanya sarana dan prasarana seperti mushola sekolah turut menunjang kelancaran ibadah siswa juga seluruh warga sekolah. Mushola sekolah selalu digunakan seluruh siswa untuk kegiatan sholat berjamaah dan kegiatan tahfidz. Faktor kematangan siswa juga sangat mendukung. Kematangan siswa dalam berfikir dan untuk melaksanakan tugasnya sendiri tanpa harus menunggu orang lain untuk membantu mengerjakan. Siswa akan lebih bisa mandiri dalam menjalankan tugasnya bukan karena ingin dilihat bagi oleh orang lain namun karena mereka berpikir itu merupakan tugas yang harus dikerjakan sendiri tanpa orang lain terlebih dulu melakukan (Aulia, 2016). Pada akhirnya, dalam membentuk karakteristik siswa di sekolah melalui sarana dan prasarana dapat tertanam sifat-sifat yang positif dan mengurangi kegiatan negatif. Keterkaitan fungsi dari sarana dan prasarana diatas tentunya dapat membentukan karakter siswa dalam meningkatkan keaktifan dalam mengembangkan potensi siswa (Kautsar \& Edi, 2017).

Siswa yang memiliki karakter religius yang baik akan senantiasa terjaga dalam kesehariannya, dengan menyibukkan dirinya pada hal-hal positif dan tidak membuang-buang waktunya untuk bermain game online. Jika nilai-nilai ajaran agama sudah tertanam dalam dirinya, maka siswa yang memiliki karakter religius yang baik akan jujur dalam mengerjakan tugas atau PR dan tidak mencontek ketika ujian, ia tahu bahwasannya sebagai seorang muslim setiap perbuatan selalu dicatat oleh malaikat, dan Allah maha melihat apa yang dikerjakannya. 
Salah satu solusi yang ditawarkan untuk menguatkan karakter religius siswa di SMP Negeri 22 Kota Jambi adalah dengan membiasakan mereka membaca surah Yasin secara rutin setiap hari Jum'at. Hal ini sejalan dengan argumen Pratikno (2016) yang menyatakan bahwa terkait pendidikan karakter maka pembiasaan dimulai sedini mungkin dan hendaknya dilakukan secara terus-menerus, teratur, dan terprogram dengan baik. Usia anak akan bertambah seiring bertambahnya waktu sehingga jenjang sekolah dasar adalah waktu yang tepat dalam menerapkan pendidikan karakter. Anak harus diberikan hal-hal yang baik karena itu akan direspon oleh otak sebagai kebiasaan baik yang kemudian suatu saat akan dijadikan sebagai sikap dan kepribadian dari siswa. Setiap anak memiliki rekaman cukup kuat dalam menerima pengaruh lingkungan sekitarnya sehingga diperlukan retensi secara berangsur-angsur.

Di SMP Negeri 22 Kota Jambi, pembacaan Surah Yasin berjamaah dilakukan rutin setiap hari Jum'at. Dengan adanya pembiasaan baik yang dilakukan secara kontinyu, maka diharapkan nilai-nilai karakter yang terkandung dalam Al-qur'an melalui Surah Yasin dapat terbentuk dalam diri siswa sebagai sebagai sebuah kebiasaan yang utuh, permanen, dan konsisten sehingga dapat diimplementasikan saat siswa berada di lingkungan keluarga, rumah, maupun sekolah, dan di masa mendatang anak tersebut akan terbentuk watak sopan santun, rendah hati, dan nilai-nilai luhur lainnya.

\section{Kesimpulan}

Tingkat karakter religius siswa kelas VIIIA SMP Negeri 22 Kota Jambi dalam kehidupan sehari-hari berada dalam kategori sangat baik, yaitu dengan frekuensi sebanyak 24 siswa atau persentase sebesar 85,7\%. Sedangkan tingkat karakter religius siswa kelas VIIIB SMP Negeri 22 Kota Jambi juga berada dalam kategori sangat baik, yaitu dengan frekuensi sebanyak 30 siswa atau persentase sebesar 96,8\%. Secara keseluruhan dapat disimpulkan bahwa siswa kelas VIIIA dan VIIIB SMP Negeri 22 Kota Jambi, memiliki tingkat karakter religius dalam kategori sangat baik, yaitu dengan frekuensi kumulatif sebanyak 54 siswa atau persentase sebesar 91,5\%.

Sarana dan prasarana seperti mushola sekolah berperan penting dalam upaya membentuk karakter religius siswa di sekolah. Mushola sekolah akan menunjang kelancaran ibadah siswa juga seluruh warga sekolah. Selain itu, kematangan siswa juga sangat menentukan tingkat karakter religiusnya. Kematangan siswa dalam berfikir dan untuk melaksanakan tugasnya sendiri 
tanpa harus menunggu orang lain untuk membantu mengerjakan dan senantiasa menjalankan kewajibannya untuk bertaqwa kepada Allah SWT.

\section{Daftar Pustaka}

Afandi, R. (2011). Integrasi pendidikan karakter dalam pembelajaran IPS di sekolah dasar. Jurnal Pendidikan Universitas Muhammadiyah Sidoarjo: Pedagogia, 1(1), 83-98.

Afifudin, M. (2016). Pengaruh ketaatan beribadah terhadap karakter islami siswa kelas VIII SMP Negeri 2 Padamara Kab. Purbalingga Tahun ajaran 2016/2017. Skripsi tidak dipublikasi. Universitas Islam Negeri Sunan Kalijaga Yogyakarta.

Aulia, L. R. (2016). Implementasi nilai religius dalam pendidikan karakter bagi peserta didik di Sekolah Dasar Juara Yogyakarta. Jurnal Kebijakan Pendidikan, 5(3), 314-323.

Ayuwanti, I. (2016). Meningkatkan aktivitas dan hasil belajar Matematika menggunakan model pembelajaran kooperatif tipe Group Investigation di SMK Tuma'ninah Yasin Metro. Jurnal SAP, 1(2), 105-114.

Azhar, K., \& Sa'idah, I. (2017). Studi analisis upaya guru Akidah Akhlak dalam mengembangkan potensi nilai moral peserta didik di MI Kabupaten Demak. Jurnal Al-Ta'dib, 10(2), 73-90.

Conceicao, P. (2019). Human development report 2019. Beyond income, beyond averages, beyond today: Inequalities in human in the $21^{\text {st }}$ century. USA: UNDP.

Darmaningtyas. (2005). Pendidikan rusak-rusakan. Yogyakarta: PT. LkiS Pelangi Aksara

Dedih, U., Zakiyah, Q. Y., Melina, J. O. (2019). Perhatian orang tua dalam pendidikan keagamaan anak di rumah hubungannya dengan perilaku mereka di lingkungan sekolah. Jurnal Atthulab, 4(1), 1-23.

Desstya, A., Novitasari, I. I., Razak, A. F., \& Sudrajat, K. S. (2017). Refleksi pendidikan IPA sekolah dasar di Indonesia (relevansi model pendidikan 
Paulo Freire dengan pendidikan IPA di sekolah dasar). Profesi Pendidikan Dasar, 1(1), 1-11.

Fauzi, A., Zainuddin, Z., \& Atok, R. (2017). Penguatan karakter rasa ingin tahu dan peduli sosial melalui Discovery Learning. Jurnal Teori dan Praksis Pembelajaran IPS, 2(2), 83-93.

Febrianshari, D., \& Ekowati, D. W. (2018). Analisis nilai-nilai pendidikan karakter dalam pembuatan dompet Punch Zaman Now. Jurnal Pemikiran dan Pengembangan SD, 6(1), 88-95.

Ghufron, N., \& Risnawati, R. (2010). Teori-teori psikologi. Jogjakarta: ArRuzz Media.

Hamdu, G., \& Agustina, L. (2011). Pengaruh motivasi belajar siswa terhadap prestasi belajar IPA di sekolah dasar. Jurnal Penelitian Pendidikan, 12(1), 90-96.

Hardiyanti, P. T., \& Nuryanta, N. (2016). Pengaruh religiusitas lingkungan sekolah terhadap konsep diri siswa-siswi di MAN Pakem Sleman. Jurnal Hisbah, 13(1), 85-101.

Hidayatullah, M. F. (2010). Pendidikan karakter: Membangun peradaban bangsa. Surakarta: Yuma Pustaka.

Indriawati, P. (2018). Pengaruh kepercayaan diri dan kecerdasan emosional terhadap hasil belajar mahasiswa FKIP Universitas Balikpapan. Jurnal Pendidikan Edutama, 5(2), 59-77.

Jusita, M. L. (2016). Pengembangan nilai-nilai karakter dalam aktivitas belajar menggunakan media pembelajaran "Pecango". Jurnal Teori dan Praksis Pembelajaran IPS, 1(1), 22-26.

Kardiyem. (2013). Internalisasi pendidikan karakter dalam akuntansi (Inspirasi) Diary (Solusi konservasi moral). Jurnal Dinamika Akuntansi, 5(1), 47-54. 
Kautsar, A., \& Edi, J. (2017). Pendidikan karakter religius, disiplin dan bakat melalui peningkatkan kualitas sarana prasarana sekolah. Jurnal Manajemen, Kepemimpinan, dan Supervisi Pendidikan, 2(2), 259-278.

Ningsih, W. A. (2017). Pendidikan karakter religius melalui pembiasaan shalat dzuhur berjamaah kelas $V$ di SD Islam Al-Madina Kota Semarang Tahun 2016/2017. Skripsi tidak dipublikasi. Universitas Islam Negeri Walisongo Semarang.

Nugraha, A., \& Rahmawati, Y. (2007). Metode pengembangan sosial emosional. Jakarta: Universitas Terbuka Departemen Pendidikan Nasional.

Pratikno, A. S. (2016). Pendidikan karakter religius melalui pembiasaan membaca Surat Yasin secara klasikal. Prosiding Seminar Nasional Pendidikan Karakter (hal. 55-61). Yogyakarta, Indonesia: Universitas Negeri Yogyakarta.

Salahudin, A., \& Alkrienciechie, I. (2013). Pendidikan karakter pendidikan berbasis agama dan budaya bangsa. Bandung: Pustaka Setia.

Santosa, A. (2014). Implementasi pendidikan karakter dalam membangun kemandirian dan disiplin siswa di MTsN Kanigoro Kras Kabupaten Kediri. Jurnal Didaktika Religia, 2(1), 21-38.

Santoso, S. (2006). Seri solusi bisnis berbasis TI: Menggunakan SPSS dan Excel untuk mengukur sikap dan kepuasan konsumen. Jakarta: PT Elex Media Komputindo.

Situmorang, P., \& Nurrahman, A. (2019). Analisis perilaku jujur siswa dalam pembelajaran IPA Terpadu materi Kalor dan Perpindahannya di SMP Negeri 6 Kota Jambi. Jurnal Nalar Pendidikan, 7(1), 71-79.

Supranoto, H. (2015). Implementasi pendidikan karakter bangsa dalam pembelajaran SMA. Jurnal Promosi, 3(1), 36-49. 
Sutrisno. (2016). Penanaman nilai religius di keluarga untuk meningkatkan kemandirian belajar siswa di sekolah. Tesis magister tidak dipublikasi. Universitas Islam Negeri Maulana Malik Ibrahim Malang.

Utami, A. T. (2014). Pelaksanaan nilai religius dalam pendidikan karakter di SD Negeri 1 Kutowinangun Kebumen. Skripsi tidak dipublikasi. Universitas Negeri Yogyakarta. 